\title{
3D Finite Elements Technique for Collapse Causes of the Pylons in Egyptian Temples: A Study of the Great Pylon of Ramesseum Temple, Luxor, Egypt
}

\author{
Essam H. Mohamed \\ Archaeological Conservation Department, Faculty of Archaeology, South Valley University, Qena, Egypt \\ Email: essam.mohamed@arch.svu.edu.eg
}

How to cite this paper: Mohamed, E.H. (2019) 3D Finite Elements Technique for Collapse Causes of the Pylons in Egyptian Temples: A Study of the Great Pylon of Ramesseum Temple, Luxor, Egypt. Open Journal of Geology, 9, 1022-1041. https://doi.org/10.4236/ojg.2019.913103

Received: December 2, 2019

Accepted: December 24, 2019

Published: December 27, 2019

Copyright $\odot 2019$ by author(s) and Scientific Research Publishing Inc. This work is licensed under the Creative Commons Attribution International License (CC BY 4.0).

http://creativecommons.org/licenses/by/4.0/

(c) (i) Open Access

\begin{abstract}
This research presents damage causes of the pylons in the ancient Egyptian temples based on 3D finite elements analysis. The main purpose of the research determines the failure causes of the first pylon of the Ramessium temple, which is situated in Upper Egypt, at Luxor "Thebes" on the west bank of the Nile River. The first pylon of Ramessium temple subjected to seismic activity effects on long term, combined with several structural damage factors such as the defects resulting from the construction technique, where the builder used the poor quality of stones in foundations of the pylon, the building materials residue was used as filler for the core of the pylon walls, and it lacked vertical joints between the courses. In addition to it founded on alluvial soil that is vulnerable to contaminated water, it is still suffering damage factors and urban trespasses at the moment. All of the former factors helped the pylon to be affected by the earthquakes loads that occurred on it. The structural behavior of the pylon under self-weight and earthquakes loads were carried out by Numerical analysis to find out the loads and stresses which caused collapsing of the pylon. Results of the study indicated that the pylon subjected to a horizontal displacement due to old earthquakes force, led to collapse of the pylon. Finally, the study represents use of modern technique to study the structural behavior of the most important architectural units in ancient Egyptian temples to identify the causes of its collapse.
\end{abstract}

\section{Keywords}

The Great Pylon of Ramessium Temple, Collapse Causes, 3D Finite Elements, Numerical Models, Horizontal and Vertical Displacement 


\section{Introduction}

The concept of conservation represents an important significance in thought of the man since pre-dynastic times, which seeks to conservation on all that has value; the architectural heritage in ancient Egypt varies between temples; tombs, pyramids, etc. The mortuary temple of Ramessium at west Thebes (Qurna) was inscribed as a World Heritage Site (UNESCO) in 1979 as a part of ancient Thebes and its Necropolis. It is located nearly $670 \mathrm{~km}$ to south of Cairo, it is situated on the west bank of the Nile, its location Latitude: $25^{\circ} 43^{\prime} 57^{\prime \prime}$, Longitude: $32^{\circ} 37^{\prime} 42.96^{\prime \prime}$, it has had many values \& significance, the most important values are: archaeological, historical, architectural and artistic values, the ancient Egyptians called the temple the "million years temple" due to its huge surface area [1]. The structures cover fifty thousand square meters.

It is also home to great statues of Ramses II that were built on the site. It took 20 years and tens of thousands of workers to build the huge complex that was dedicated to the God Amun. This temple was constructed to serve two purposes; the one that the temple was publicly built to allow the ancient Egyptians to practice their religious rituals, including prayer and ritual offerings to the gods, the second purpose, it was constructed to show the Pharaoh's greatness and his political and military accomplishments, and perhaps more so (Figure 1).

All the structures in front of the pylon have disappeared today and are now being covered over by the farmland. We can imagine there was a forecourt with a monumental entrance and a dromos between the quay and the pylon. The pylon, whose eastern side is now totally ruined, most certainly had two flag masts on each of its piers; it marked the temple entrance and the first courtyard.

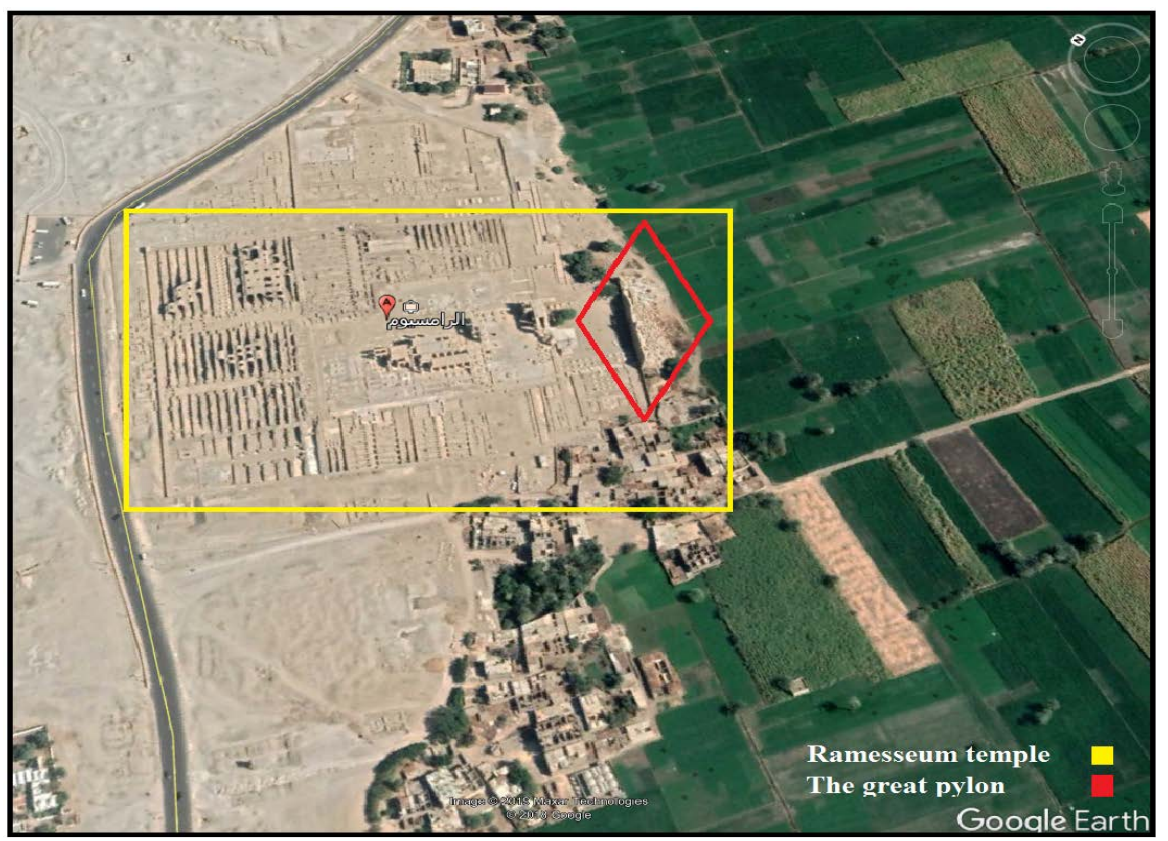

Figure 1. The site of Ramessium temple and the farmland in the eastern side of the great pylon. 
The Egyptians considered their monuments to be charged with the preserved western side of the pylon being decorated with war campaign scenes, notable episodes from the famous battle of Kadesh (a central Syrian city) waged against the Hittites. Thanks to certain literary pieces, this battle is known about: the war report and Pentaour's poem. This battle is also illustrated in Abydos, Karnak, Luxor and Abu Simbel temples [2] [3].

The temple has been suffering damage factors and causes since ancient times because of the earthquakes and ancient flash flooding, it is also suffering damage factors and causes at the moment such as agricultural, groundwater raised, housing, urban trespasses and man-made destruction, pollution and infection of groundwater beneath the temple and its site and higher plants growth. This temple has not received enough attention from specialists in architectural conservation, particularly, the great pylon of the temple, which is totally ruined. Structural damage is caused by any negative changes that may affect the structural behavior of the building, due to increased mechanical effects or a reduction in the structural efficiency of the building elements, due to the impact of various damage factors [4]. In most cases, the damage is exacerbating by the structural design of the monumental buildings, which is inappropriate for the seismic loads. Many monumental buildings had suffered severe effects; some of them were collapsed (totally or partially). Structural damage causes of monuments are showing in three of the problems that affect on the buildings, namely: seismic action, soil differential settlement owing to the variability of the groundwater table, and material deterioration.

Structural damage of architectural heritage occurs due to the impact of earthquakes, differential settlement, rotation, or any other effect of the interaction between the structure and the soil [5] [6].

The success of the structural restoration project mainly depends on the accuracy of the diagnosis, which is to identify the causes of damage and deterioration. The aim of this paper is to know the collapse causes of the great pylon of Ramessium, through study the structural behavior under the effect of self-weight and earthquake loading.

In this research, the architecture, the construction, and the chronological development of the pylons used in ancient Egyptian temples were briefly investigated. Afterward, 3D F. E. M numerical static and seismic analysis; taking into account soil and structural features in order to assess the real safety levels and the weakest areas and safety factors, the current state of damage and conservation proposals for the great pylon of Ramessium temple.

\section{The Pylons in Ancient Egyptian Architecture}

\subsection{Chronological Development}

The pylons were clearly spread in the early New kingdom; however, we still don't know the source of its innovation. It may also have been known during the Middle Kingdom; however, where we found very little of its ruins at that time; 
the excavations were per-formed in the Ashmunin city of Hermopolis, revealed the foundations of some pylons of a temple dating from the Twelfth Dynasty. In Memphis, Petri discovered elements of one of the pylons, dating back to the Twelfth Dynasty. It is also noted that the temple of Medamud, which was built during the first intermediate period, was attached to a huge pylon. In one part of Abydos temple, built during the Sixth Dynasty, excavators have found stone blocks with several longitudinal lines: Petri sees it as remnants of some pylons.

Finally, within the sun temple, in which back to the king of Nyuserra (Fifth Dynasty), it was observed that two distant areas facing each other, in the facing of courtyard that surrounding with the pyramid, it was built slightly diagonally, thus creating two towers, which could be considered as the prototype of the known traditional pylon.

The ancient Egyptians were believed that the pylon symbolizes to the horizon, as a corridor between two mountains (Baju and Manu), in which the sun rises, the ancient Egyptians were thought that the sun is rise between its two towers, which are theoretically head to the east, then enlighten the temple and its rays reach to the Holy of Holies [7]. Certainly, the pylons were associated with Isis and Nephthys, they were thought to have served as guards of the god, which is in his holy place in the temple. The oldest examples of the pylons in ancient Egyptian architecture appeared from the eleventh Dynasty until Ptolemaic Period, there are examples dating back to the first intermediate period, wherein the Madamud revealed Osiris temple originally composed of a pylon leading to a courtyard with a corridor, and there during the era of Amenemhat III and IV, the harvest god "Renot", the crocodile god "Sobek" and the god Horus temples were constructed [8] [9]. The oldest pylons in ancient Egyptian architecture Those that exist in temples of the New Kingdom (1550 - 1069BC) in Thebes, such as Habu, Ramessium, Luxor and Karnak temples [10], The first pylon of Luxor temple in Thebes and the pylons of Horus temple in Edfu (237 - 57BC) are considered the most important architectural units that still exist to this day.

\subsection{Architecture and Construction}

The pylon is considered a huge build consist of two towers in which symmetrical shape, between them a door connecting to the open courtyards and roofed columns. The pylon facade is ample from the undermost, and narrows whenever it rose, it is interspersed with a number of Entries ranging from two to eight and has been dedicated to the installation of temple flags, the façades of pylons were ornamented with huge wooden flagstaffs (reaching $30 \mathrm{~m}$ in height) capped with colorful cloth flags, The flagpoles were carved from individual wooden beams that brought from the forests of modern-day Lebanon or northern Syria from, these flagstaffs were often tipped with invaluable metals that reflected the rays of the sun [11] [12] (Figure 2).

The techniques used to in the construction of pylons of the temple were derived from the incomplete temples that provided us with information about the method used in the process of building; the first pylon in Karnak is considered 


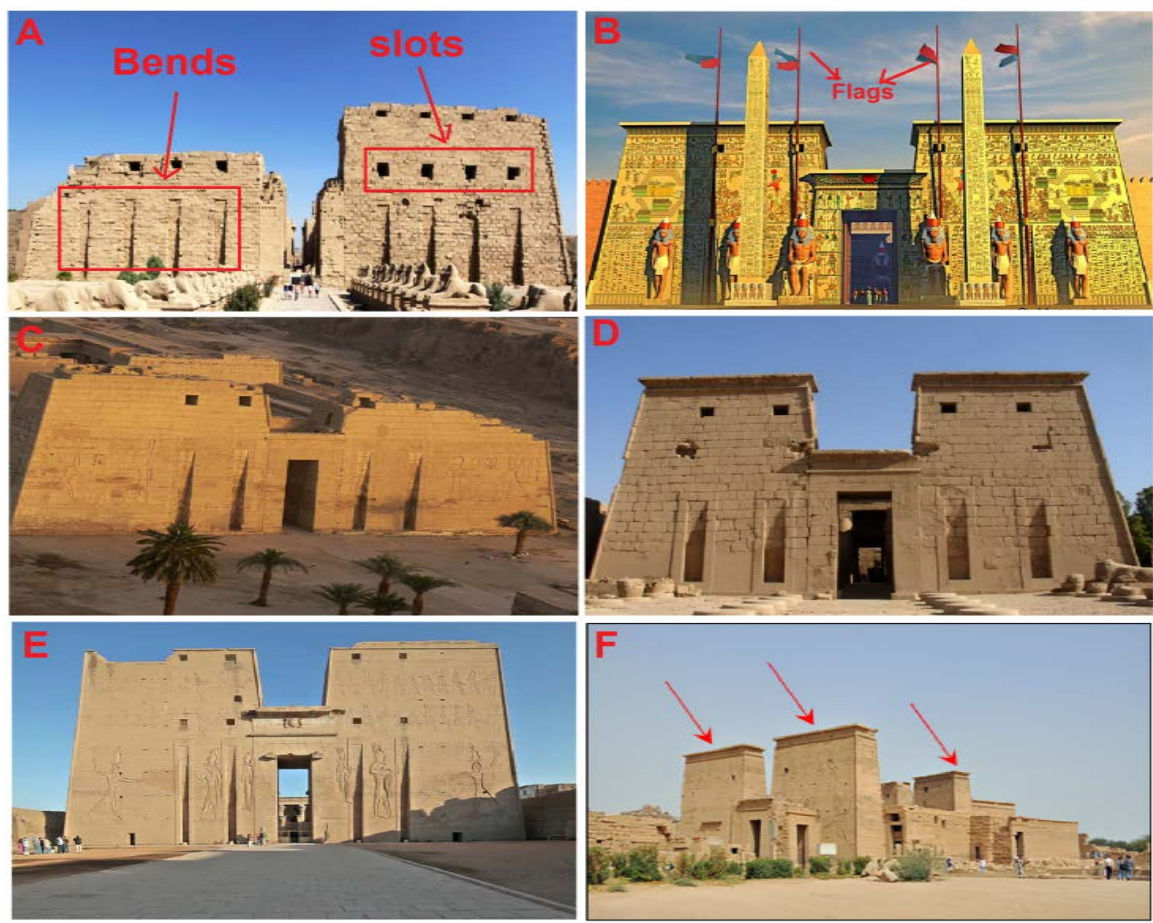

Figure 2. Different shapes of the temples pylons (A) Shows the slots and the bends in the pylon which use to put the flags (Karnk temple). (B) Imagine shape to the external facade of the first pylon of Luxor Temple. (C) The first Pylon of Rameses III temple (Habu city). (D) the pylon of Khonsu temple. (E) The first Pylon of Edfu temple. (F) The pylons of Philae temple.

the most important source for understanding the construction of stone pylons typical of the Egyptian temples. Around the unfinished first pylon of the temple, there are remains of mud brick ramps, which are considered important evidence on using it to access to the upper courses of the wall (Figure 3(A), Figure 3(B)), in addition to the signs of cutting of the stones that still exist and witness to the process of quarrying of the stones. Generally, the foundations are the most important in the construction process because of its large structural role in bearing the stresses on the building as a whole. The foundations consisted of a trench dug down from ground level and partly filled with clean, dry sand (Figure 4), The use of layers of sand in building foundations was for two purposes; firstly, it protects the foundations from the erosion of groundwater, secondly, it protects the foundations from the effect of earthquakes by absorption the wheel acceleration of horizontal and vertical earthquakes, due to its flexibility. Ancient Egyptians used to usage rubble stone in foundations of the pylons, taking into account that the foundation is wider than the walls which above them, this method serves to strengthen the load bearing walls. According to the construction style in ancient Egypt, courses of blocks were laid down and leveled, to providing a regular surface for a building's superstructure [13] [14]. In the 15th Dynasty, the foundations of the pylons were got better in quantity and quality; and it became deeper, to giving more strength and support to the walls of the pylons (Figure 3). In the Middle and the New Kingdom, the building techniques were 


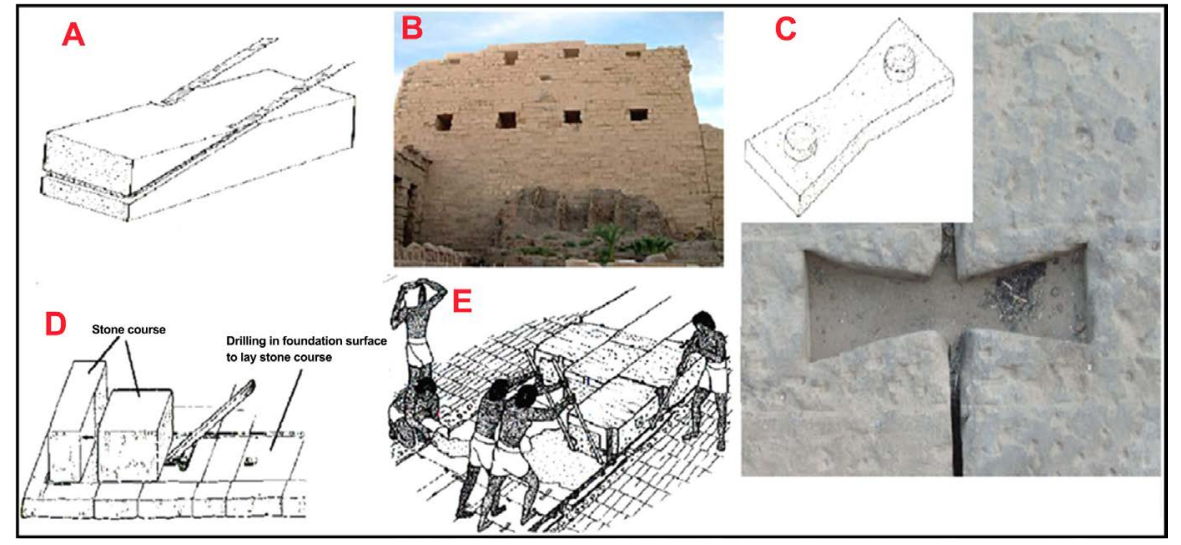

Figure 3. Methods of construction of the wall courses. (A) Using the ropes to pull the stone. (B) Mud brick ramps. (C) The stone dowels which use for connecting the blocks together. (D) Using a crow-bar to moving the blocks. (E) Using the mortar in installation of the blocks.

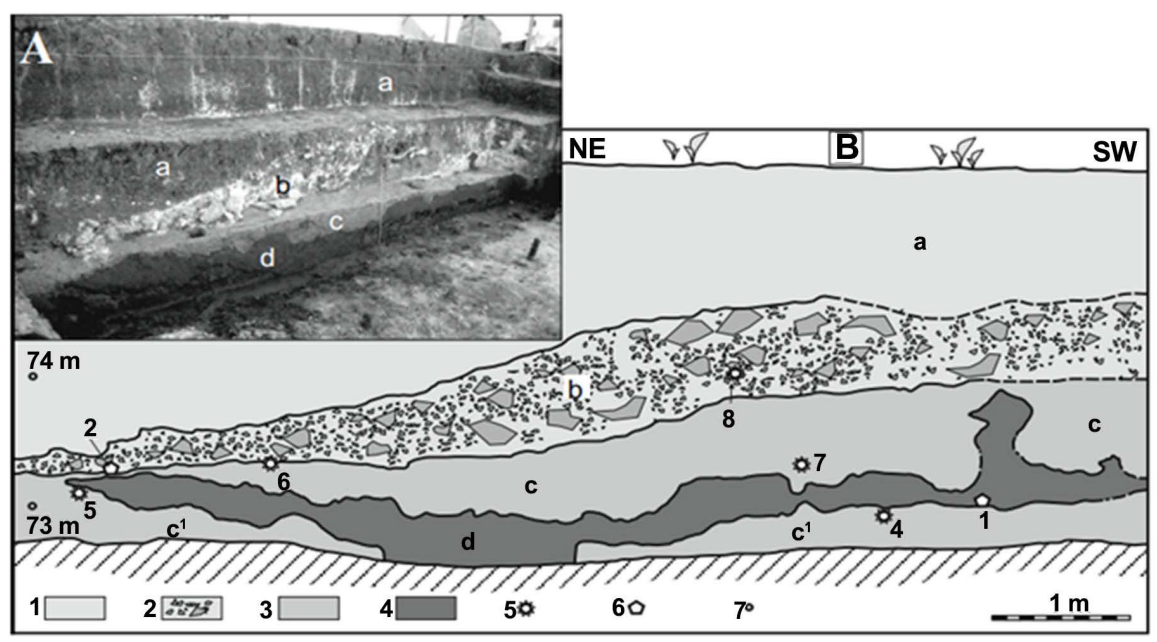

Figure 4. Shows a Trench at the second pylon of Amenhotep III temple, (A) Photo of the trench and (B) trench log. 1-soil rich in silt and organics brought by seasonal floods of the Nile (layer a), 2-destruction layer (b), 3-dense clay above (layer c) and below $\left(c^{1}\right)$ the dike, 4-sand dike (layer d), 5-14C sampling locations, 6-ceramics sampling locations, 7-elevation mark of $74 \mathrm{~m}$ above sea level (after: Karakhanyan et al. 2010).

developed, where they used the bricks in as retaining walls of the trenche of the foundation to avoid the soil collapse, in the Ptolemaic period, the construction techniques were developed, more substantial blocks were used to support the superstructures, this is clearly demonstrated in the temples of Dandara, Edfu and Kom Ombo. After the quarried stone arrived at the building site, the bobbins, ropes and a crow-bar were used to moving the blocks towards their place in course of the wall (Figure 3(A), Figure 3(D)). It would be given dressing on any side that would later come into link with other stones. The stones of one course would be then placed together in a row and each individually cut along their sides, sometimes with irregular or deflector angles, and combined together by stone dowels in course of the wall (Figure 3(C)) [15], after the wall grow verti- 
cally the workers reaching the top of the wall via mud brick ramps to dress the upper face of the blocks (Figure 3(B)), usually they used liquid mortar to joint the blocks together (Figure 3(E)).

Workers used to employment large rectangular stones of slightly differing shapes and sizes without undressing in the once course of the wall as a kind of rationalization of consumption in stone blocks, set together with irregular joints. These were set in courses of varying height; the 18th and 19th Dynasty pylons at Karnak provide good examples of this typical form of construction (masonry). This technique was used occasionally in which blocks are cut to a uniform size and walls assembled in courses of parallel heights, this method was discontinued in the New Kingdom, but it was taken up again at Karnak during the 25th Dynasty with larger sized blocks, the walls were composed of standardized courses. In general, they used to employment high quality stone in the outer casing of the pylons, but the core of the wall itself was often composed of local, poorer quality materials, or reused blocks of collapsed buildings [11]. In Ptolemaic and Roman period the builders introduced a different construction technique, where used the layers of liquid plaster which were added to courses of stone to assist with the placement of the following layer.

\section{The First Pylon of Ramessium Temple}

\subsection{Architecture and Construction}

The distinct structure of this complex corresponds to an evolution in the funerary temple idea: the grave was concealed deep in the hill and the temple was constructed on the edge of the desert region facing the Nile and the east bank temples. This idea combines the pure funeral function with the resting location of Amun's bark; for instance, during the west bank processions, especially the Beautiful Valley Festival. This evolution in funerary architecture culminates in the time of Ramesses II in a real divine temple. This kind of temple had its own local form of the God Amun with which the deceased king was recognized as a god. Ramessium's temple includes an area of about 6 hectares (N-S 220 m; E-W more than $280 \mathrm{~m}$ ) in its entirety. The two stone temples are situated in the center of the complex and around them, on three sides, on the north, south and west sides; there are annexes and mud brick houses. These structures, with their excellent surviving vaults, have just produced the storerooms [16]. The pylon considered one of the most important architectural unites in the ancient Egyptian architecture, for its religious and symbolic significance. The temple was accessible from the Nile in ancient Egypt through a canal which likely ended at a quay in front of the large pylon which was $69.38 \mathrm{~m}$ long and about $22 \mathrm{~m}$ high (Figure 5), a stairway which led from the northern side gave access to its summit. The pylon, whose eastern side is now completely destroyed, had two flag masts on each of its piers, the main entrance situated in the eastern side of the pylon, it was decorated with scenes of the Kadesh battle, but it is now in ruins. On the right side of the pylon, you will discover inscriptions representing the 118 cities 


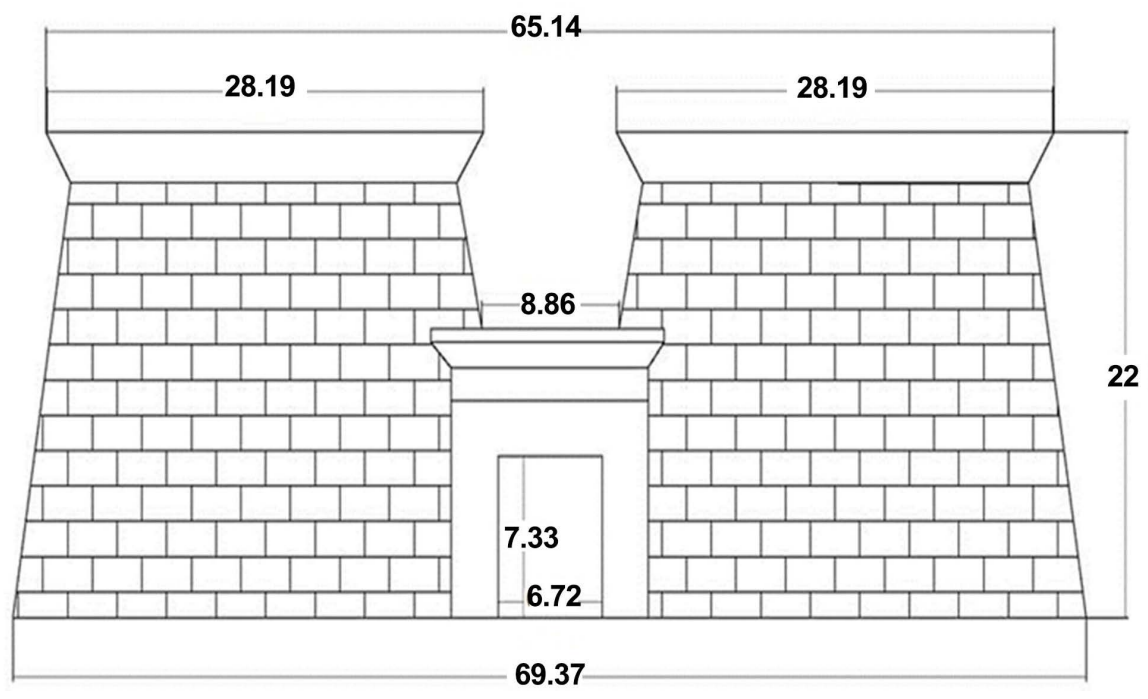

Figure 5. Shows the elevation façade of the first pylon of Ramessium temple.

conquered by Ramses III during his military campaigns; you'll also see scenes taken to the King by inmates. There are scenes from the renowned fight between Ramses II and the Hittites on the left side of the pylon. You will then continue to the first open courtyard, where many damaged statues will be seen.

\section{Structural System}

The structural system of the first pylon of Ramessium temple is summarized in the following:

1) Select of the site: determine the site of the pylon that is situated in the front of the temple, it included on the main entrance in the middle; it shall be perpendicular to the Nile River and head from east to west with the direction of the temple.

2) Foundation system: the ancient builder followed several steps in the construction of the pylon we summarized in the following: a) gypsum is scattered on the ground to determine the horizontal design of the pylon. b) The foundation of the pylon consisted of a trench mined down from ground level and partially filled with clean, dry sand. c) The blocks laid in trenches upon a bed of sand and were leveled, to providing a regular surface for a building's superstructure; remains of the stones were used as a core for the pylon foundation. d) After completing of construction of the pylon foundation, channels carved carry out into the horizontal surface of the last course of the foundation, providing a uniform surface to cohesion the courses together.

3) The construction system: a) the stones of one course were placed together in a row and each individually cut along their sides and combined together by stone dowels. b) Channels were carved in all surfaces of courses of the wall; these diggings were filled with a bonding mortar to ensure that the blocks cohesion to each other. c) The field study showed that the construction courses of the first pylon are almost equal (Figure 6); the joints between the blocks were filled by fractures of small stones from the remains of the quarrying process. 


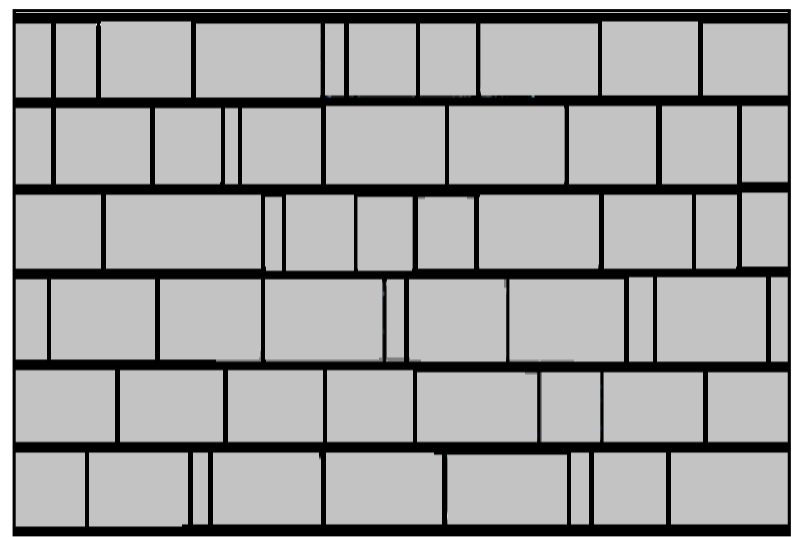

Figure 6. Shows construction style of courses used in the construction of the walls of Ramessium temple, where the arrows indicate the vertical joints between stone blocks.

\section{Notes on the construction style of the first pylon}

The first Pylon of the Ramessium temple was founded on alluvial soil that is vulnerable to water, due to that the ancient builder didn't realize effect of the soil type on the foundations, in addition to using shallow trenches in foundation process. These the trenches were filled with loose rubble, chips of dressed stones and reused material because of may be technical or economical reasons (Figure 7).

1) The poor quality of foundations of the pylon where the builder used a few courses of friable stones to economize in the consumption of stones, the foundation of the pylon gate was built separately from the foundations of the pylon itself.

2) The ancient builder used high quality sandstone as the outer casing of the pylon where the wall blocks are cut to a uniform size and assembled in courses of parallel heights.

3) The walls of the pylon were built of separate courses and the limestone residue was used as filler for the core, the blocks were horizontally assembled together by stone dowels, but it lacked vertical joints between the courses.

4) Lack of interest in the process of adhesion between the blocks and links in the walls of the Pylon, where the pylon was built from two parallel walls between them filler of rubble and reused stones.

5) The eastern side of the pylon is totally ruined now, and the western side is suffering from different sizes, shapes of cracks, and partially loose of the wall. The northern side was destroyed more than the southern side of the pylon.

6) We are observed different weathering forms in the pylon's stones, such as loss of stone material, missing parts, erosion of stone surfaces, exfoliation, efflorescence of salt, Pitting, peeling, and granular disintegration.

\subsection{Causes of Deterioration of the Pylon}

The pylon has been suffered from different damage factors since the time of construction as a result of defects in construction technique, soil settlement due 


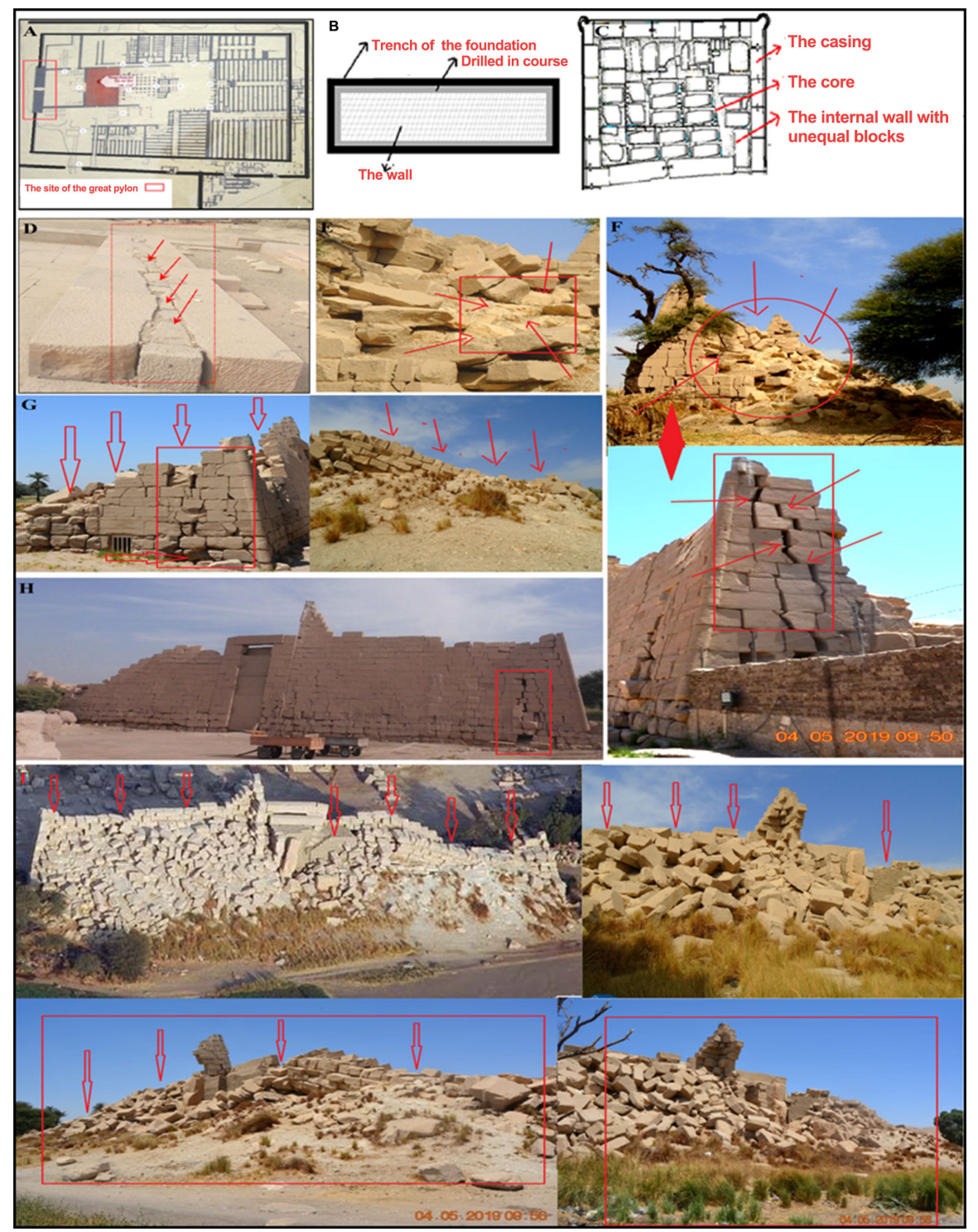

Figure 7. Shows different deterioration symptoms of the first pylon of the Ramessium Temple (A) Shows site of the first pylon of the Temple (Horizontal Design). (B) Cross section of foundation of the pylon. (C) Longitude section of the first pylon. (D) (E) Shows building technique of the pylon, where show rubble and reused stones which used as a core for the pylon. (F) The southern side of the Pylon, where shows wide cracks in the wall and partial loss of the wall and separate of the blocks. (G) The northern side of the Pylon shows partial loss and more destroyed of this side. $(\mathrm{H})$ The western façade of the Pylon shows different cracks, settlement in the southern side and partial loss in the upper parts of the façade. (I) The eastern façade of the pylon shows totally ruined.

to the effect of groundwater and emergency damage factors, such as flooding or earthquakes.

\subsubsection{Foundation and Construction Defects}

The pylon was founded on the clay soil, this kind of the soil is impermeable so; it is affected by raise groundwater level, as a result size of the soil expands due to increases of moisture content of the soil, when the moisture content is de- 
creased, size of the soil is shrinked, expansion and contraction of clay minerals leads to damage of the foundation soil which affects the buildings, the groundwater containing various kinds of mineral salts, in which they are the most important physio chemical weathering and damage processes that affect building materials of the foundation [17], the foundations are damaged because of effect of dissolved salts, where led to erosion and weakness it.

This is what happened in the soil beneath the pylon, which led to an irregular settlement. The stones of poor quality that were used in the core of the pylon foundation were greatly affected by soil damage, which helped on settlement of the building, in addition to that shallow trenches of the foundation led to non-resistance of the foundation to overload of large building units [18].

The weakness of the foundations led to intolerance to the static effects of dead loads resulting from the self-weight of the huge blocks. It was found that use of different building materials in construction of the pylon's foundation leading to occurrence of imposed stresses on the building, due to different of coefficients of expansion and contraction of these materials when exposed to various damage factors [19].

According to construction style in ancient Egypt, particularly in the New kingdom period the walls of the pylon consisted of two outer walls, and the interior core was filled with mixed, reused and rubble blocks. The construction style which used in the pylon was one of the most important factors that helped in collapse of the building, where the interior core was filled with reused blocks which readily damaged because of affecting raise groundwater level, resulting in a fall for this filler and thus the malfunction has occurred in the structural system of the pylon, so these masonry become fissured and subjected to damage from vibration, the core will separate, leaving the outer walls to carry the loads in full, for this reason, various sizes of cracks were appeared in different places of the pylon. It was also found that the weakness of the vertical links in the wall led to the building subjected to increased stresses.

Finally, there are constructional defects resulting from the building style that was followed in construction of the pylon, these defects helped jointly with different damage factors in appear different construction damage symptoms, such as collapsing in the main façade of the pylon, fall down of the interior core, cracks in different sizes, loss of stone materials, partial loss in walls of the pylon, separation of stone blocks from each other.

\subsubsection{Seismic Damage on the Pylon of the Ramesseum Temple}

According to several seismic and geological studies during different periods of time, many archaeological buildings were destroyed in Thebes and Middle Egypt [20] [21] [22], where related the damages in the Luxor and Karnak temples to some historical earthquakes [23]. Ramesseum temple subjected to several seismic damages during the Pharaonic period and until the last century [22] [24] [25] [26]. The Egyptian National Seismic network reported earthquakes ranging from 4 to $\leq 2$ in the region of Luxor and to the south-southeast, at a distance of 
170 - $190 \mathrm{~km}$ northwest of Luxor, there were three earthquakes between Sohag and Assiut with magnitudes between 4 and 5 in 1998, 1999 and 2003 (Table 1). When the pylon exposed to the impact of earthquakes, it suddenly subjected to irregular movements and vibrations, these vibrations resulted to horizontal effects, which represent riskiness on the structural elements of the pylon due to that its rates and intensity have been changed several times per second. In addition to the effects of horizontal displacement affecting the building we must to put in our consideration weak soil and high groundwater level.

Accordingly, the underlying layer's liquefaction and deformation will produce vertical cracks in the upper soil and break it into different blocks, which then travel horizontally or in the direction of the slope gradient (i.e. towards the river). The blocks bend and tilt to different sides, amplifying the destructive seismic effect repeatedly and causing the surrounding structure to experience the greatest damage. The blocks bend and turn on different sides, continuously amplifying the catastrophic seismic effects and causing the most serious damage to the surrounding structure. This influence likely facilitated the Ramses II temple's extreme destruction [27].

The structural design of the pylon resists the vertical loads resulting from dead loads of large stone blocks, but doesn't resist the horizontal displacement resulting from earthquake movement because the ancient builder didn't care about vertical block joints, in addition to that the pylon consists of two outer walls, and the interior core was filled with mixed, reused and rubble blocks, as a result, there was no moment transfer between these elements, which resulted in the building hasn't bear the horizontal displacement of earthquakes.

In addition to the previous reasons which are responsible for structural damage of the pylon, there is another factor affecting in damage mechanism, the sandstone is the main building material of the pylon has low ductility, therefore it is greatly affected by horizontal displacement of the earthquakes. The tensile force that occurred due to the earthquake's effects led to varying severity damage such as cracks in the walls which is characterized by varying depth and breadth or separation of architectural elements, cracking and collapse on the long term.

Table 1. Summary of historical earthquakes in Upper Egypt.

\begin{tabular}{cccl}
\hline Time & Location & Richter scale & Seismic damage \\
\hline 600BC & Luxor & 6 & Damage occurred in Thebes temples \\
28-27BC & Luxor & 6 & Cracking and collapse in Ramesseum temple \\
967AD & Upper Egypt & 6 & Damage occurred in Karnak temples \\
1778AD & Upper Egypt & 6 & Damage occurred in Thebes temples \\
$1850 \mathrm{AD}$ & Upper Egypt & 6 & The earth's crust has been affected in upper Egypt \\
$1899 \mathrm{AD}$ & Upper Egypt & 6 & Damage occurred in Ramesseum temple \\
$1981 \mathrm{AD}$ & Kalabsha & 5.6 & Low affecting occurred in Aswan and Luxor \\
$1984 \mathrm{AD}$ & Abou Diab & 5.1 & Low affecting occurred in Aswan and Luxor \\
\hline
\end{tabular}




\section{Structural Analysis of the Pylon}

In recent years, (FE) computer programs have made it easier to perform detailed nonlinear dynamic analysis; the objective was to understand the structural behavior of historic masonry building under the different loading conditions [28] [29]. 3D numerical model of the first pylon of the Ramesseum temple was carried out using the finite elements (FE) software SAP2000. Finite elements analyses are carried out to determine the structural behavior of the pylon under different loading, these loading included the self-weight and earthquakes effects.

\subsection{Structural Analysis under Seismic Loads}

Equivalent static load (simplified modal response spectrum) was used for structural analysis of earthquakes loadings. In this method, the dynamic forces resulting from earthquakes are converted to horizontal static force, to study its effect on the building, building materials, construction style of the pylon, and kind of the foundation soil are taken into consideration.

$$
F b=S d(T 1) \times £ w / g .
$$

$F b=$ Ultimate shear force.

$S d(T 1)=$ Response spectrum

$G=$ gravitational acceleration.

$T 1$ = Fundamental period of the building.

According to the previous Equation (1) and curve response spectrum, the values of the equivalent horizontal forces affecting on the front facade of the pylon are shown in Figure 8.

When the pylon is exposed to horizontal earthquakes loads, the horizontal forces attempt to overturn the building, the pylon weight works to balance of the building against these forces, the shear force affecting on the pylon shows in, where we observe that value of the shear force increase in the lower parts of the pylon, which amounted to 2233 tons (Figure 9 and Figure 10).

Weight of the pylon $(W)$ :

- Side facade area $=0.5 \times(14+10.5) \times 22=269.5 \mathrm{~m}^{2}$ (Figure 11).

- The volume of the left part of the pylon $(V)=$ Side area $\times$ Part length.

$$
=(269.5) \times(31.9)=8490 \mathrm{~m}^{3} .
$$

The weight $(W)=$ Density $(D) \times$ Volume $(V)$.

$$
=1.9 \times 8490=16131 \text { Ton. }
$$

Total weight $(W t)=16131 \times 2=32262$ Ton

$M$ stability $=W t \times \mathrm{B} / 2=32.262 \times 7=225.83 \mathrm{~T} \cdot \mathrm{m}$.

$M$ overturning $=152.922 \mathrm{~T} \cdot \mathrm{m}$.

$$
\begin{aligned}
& M \text { stability } / M \text { overturning } \geq 1.5 \\
& 225.83 / 152.922=1.47<1.5(\text { Unsafe })
\end{aligned}
$$

According to the Egyptian Code of Earthquake Loads, $M$ stability/ $M$ overturning should not be less than 1.5 (Figure 12), so the pylon was not safe to withstand the earthquake forces, where the value of Equation (2) was less than the safety limit, as a result, the pylon collapsed. 

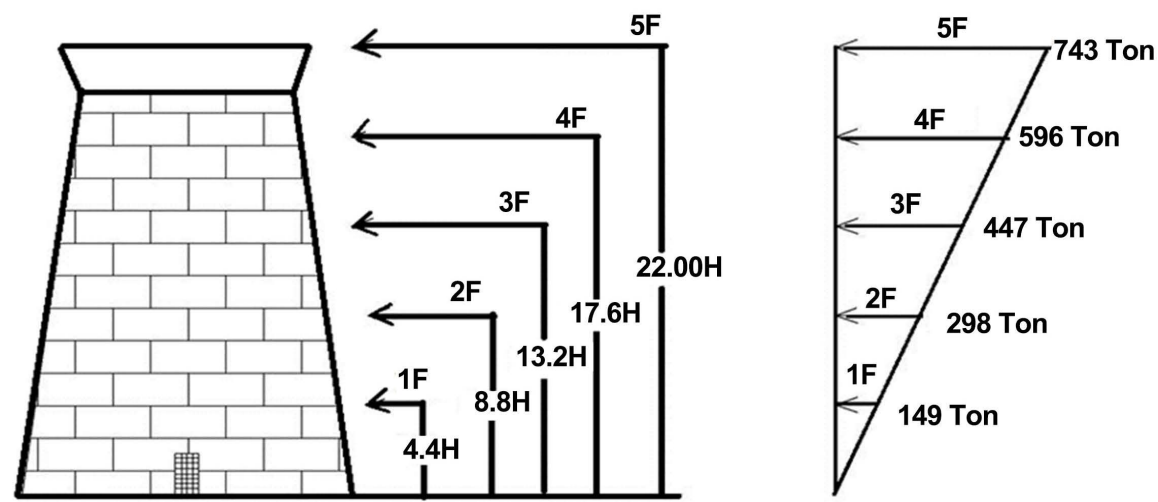

Figure 8. Shows the values of the equivalent horizontal forces affecting on the front facade of the pylon.

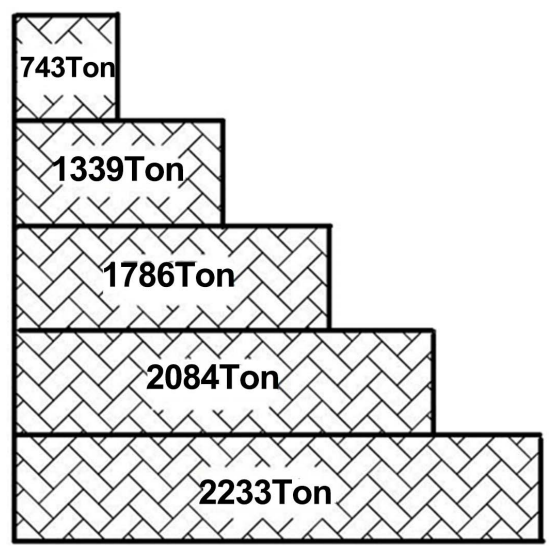

Figure 9. Shear force daigrame affecting on the front façade of the pylon.

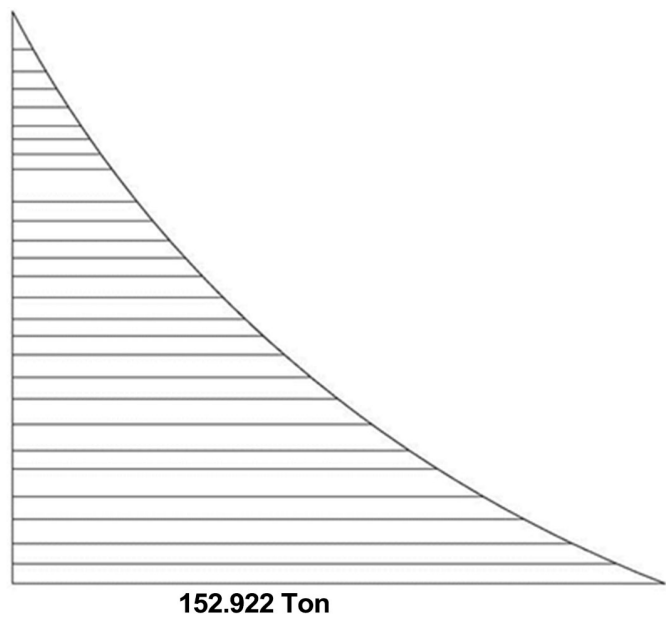

Figure 10. The moment curve affecting on the pylon, due to earthquakes loadings.

3D finite elements used to understand the structural behaviour of the pylon under seismic loads. The resultant deformations are shown in Figure 13. Which represents the displacement values of the structure in the direction of the axis 


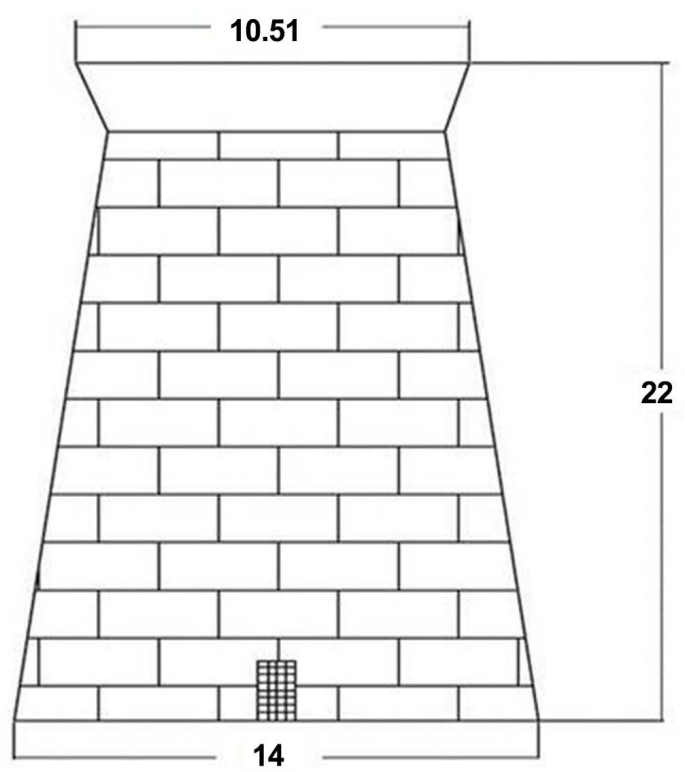

Figure 11. The side façade of the pylon.

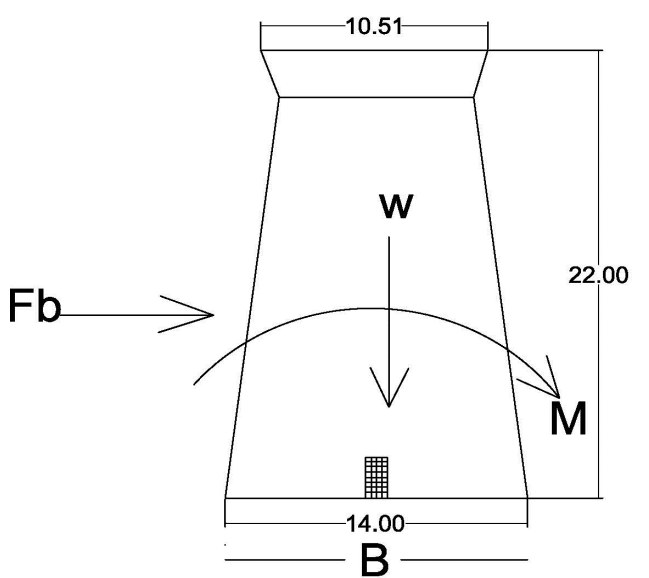

Figure 12. Visualize to check overturning.

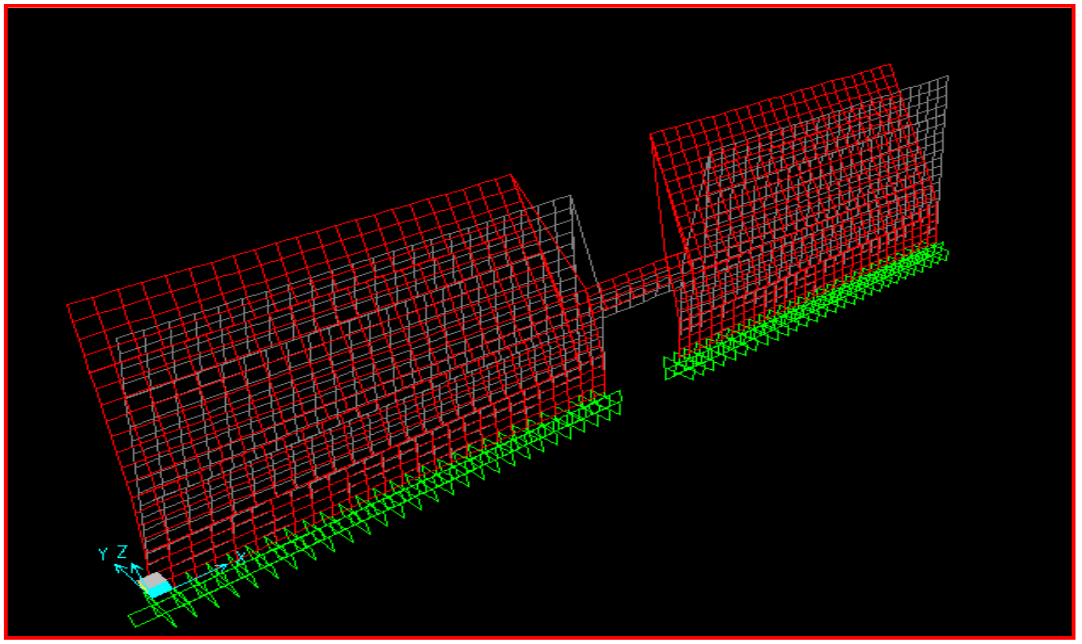

Figure 13. Horizontal displacement diagram in the direction of the axis $(\mathrm{x}-\mathrm{x})$. 
(y-y). According to the Egyptian Code we can calculate the horizontal displacement value by the following equation:

$$
\operatorname{Dr} / V=0.005 \mathrm{H}
$$

Dr. Displacement calculated from the program.

$V$ (Coefficient depends on the seismic zone $)=2.5$.

$H($ Diagram $)=4.4 \mathrm{~m}$.

$D r / V=0.005 \mathrm{H}$.

$26 / 2.5=0.005 \times 4400$.

$10.4<22$.

From the previous result, it is shown that the horizontal displacement of the building did not exceed the safety limits according to Egyptian code.

Prokon program was used to find maximum Moment resistance $(\mathrm{Mr})$ that structure can tolerate without cracks, which reached to (22.95) $\mathrm{n} / \mathrm{mm}$ according to the structural design of the pylon.

After the structural analysis of the SAP program we set limits for the moment by the value of ( $\mathrm{Mr}$ ) that was taken out of Prokon program, where the largest values of $(\mathrm{Mr})$ represent the areas subject to cracks and collapse as shown in Figure 14. The resultant deformations indicated that corners of the pylon are most of the places that have been exposed to the stresses more than the limit permissible (Figure 15).

\subsection{Structural Analysis under Dead Loads}

3D finite elements used to understand the structural behaviour of the pylon under dead loads, the maximum vertical displacements diagram of the pylon under dead load is shown in Figure 16, it can be seen from resultant deformations that the vertical displacement have an increasing trend from sides and middle of the building.

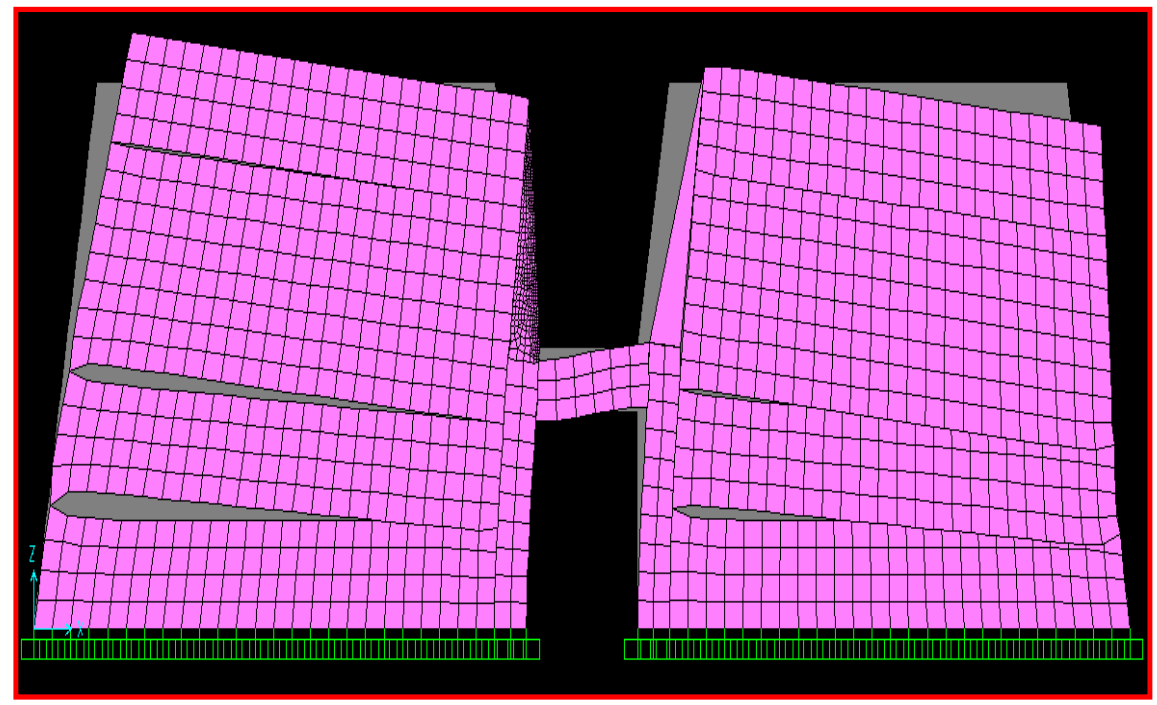

Figure 14. The horizontal displacement diagram in the direction of the axis (y-y). 


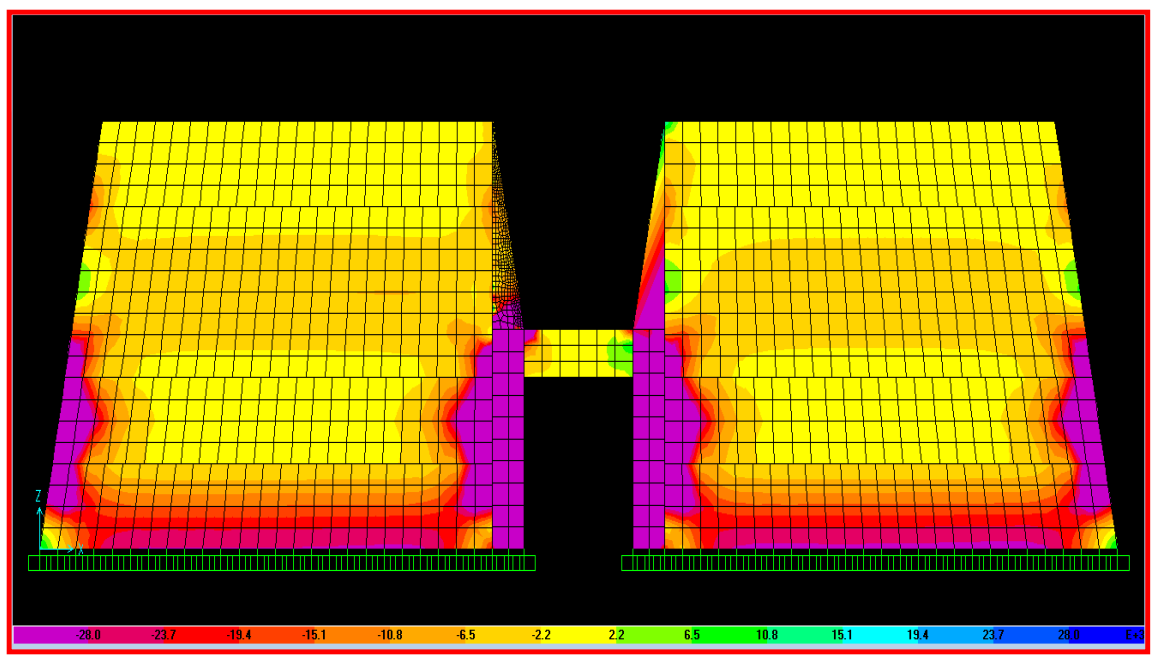

Figure 15. Resultant deformations of the great pylon of Ramesseum temple under seismic loads.

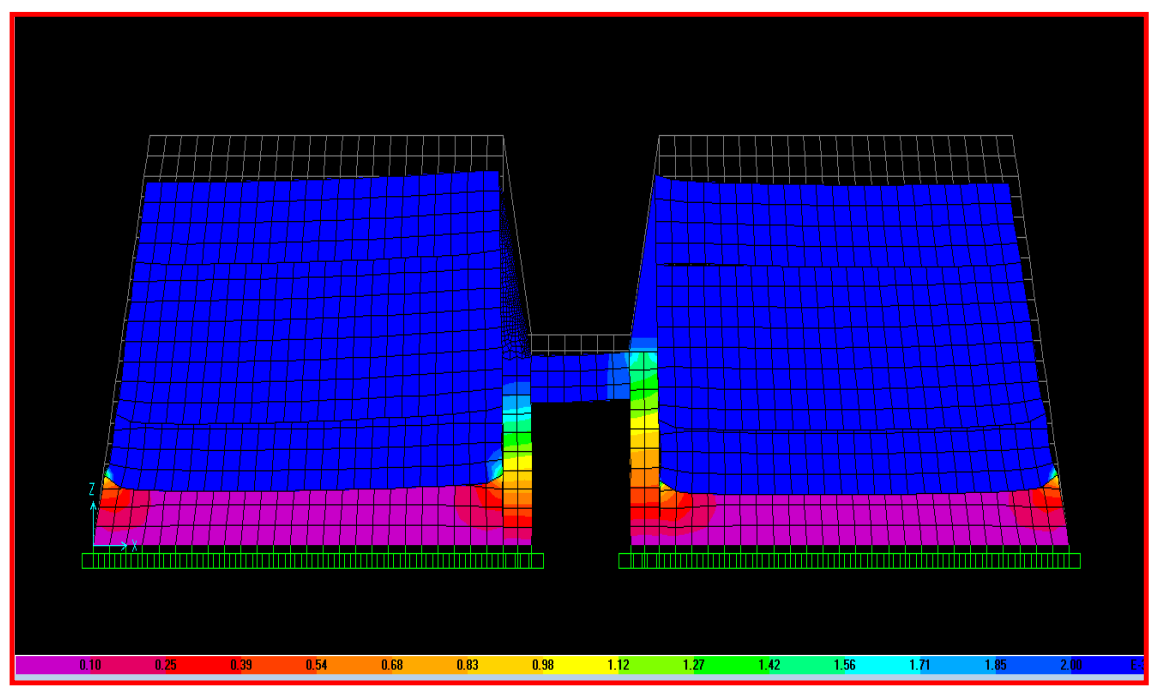

Figure 16. Resultant deformations of the great pylon of Ramesseum temple under dead loads.

\section{Results and Discussion}

After finishing the analysis of the pylon, the resultant deformations are shown in Figures 14-16, where Figure 14 and Figure 15 represent the structural analysis under seismic loads, and Figure 16 represents the structural analysis under dead loads. The results indicated that the pylon subjected to horizontal displacement resulting from earthquakes stresses and vertical displacement of dead loads of the building.

The study concluded that the first pylon of Ramesseum temple subjected to collapse due to the effect of horizontal displacement and shear force of old earthquakes jointly with construction defects and different deterioration factors, the previous results showed that the pylon was designed to resist dead loads but not suitable to resistance of earthquake loads, this explains collapse causes of the 
pylon, when it subjected to old earthquakes effects, in addition to other damage factors.

\section{Conclusions}

The paper presented a study carried out on the first pylon of Ramesseum temple which dates back to the 19th Dynasty of Pharaonic period to determine its collapse causes. The pylon is totally ruined because it subjected to old earthquakes jointly with construction defects and different deterioration factors. 3D numerical model of the first pylon of Ramesseum temple was created using the finite element (FE) software SAP 2000 to understand the structural behavior under the different loading conditions (earthquakes and self-weight loads) that the pylon had undergone to. This method contributed to identifying force and weaknesses points of the pylon, from which we are concluded that the collapse causes of the pylon is the dynamic loads represented by the horizontal and vertical acceleration wheel of the old earthquakes, in addition to the random filling of construction blocks of the core of the pylon and neglecting vertical joints between the building courses.

The study concluded that old builder did not take into account in structural design of the pylon that it bears the dynamic loads it might subject later.

The study results give way to us to find the appropriate method to the intervention with reconstruction of the pylon, including the preservation of original pylon blocks with establishment a core of hollow reinforced concrete to install the external blocks of the pylon walls on it, with no adhesion of the original blocks with the modern building's core, in addition to consolidation of the soil with establishment striped foundations of the treated concrete beneath the pylon, taking into consideration that the core of the build is resistant to earthquake loads, and the historical and architectural values of the pylon are according to international conventions and standards.

\section{Acknowledgements}

I would like to thank Eng. Barakat Heshmat Mohamed, consultant of the civil engineering of Gamaan office for engineering consultancy and geotechnical laboratories, for his cooperation and valuable efforts in this research.

\section{Conflicts of Interest}

The author declares no conflicts of interest regarding the publication of this paper.

\section{References}

[1] Mapunda, B.B. (1996) An Archaeological View of the History and Variation of Ironworking in South Western Tanzania. https://elibrary.ru/item.asp?id=5616259

[2] Kuentz, C. (1928) La bataille de Qadech: Les texts.

[3] Lipinska, J. (1969) Amenemone, Builder of the Ramesseum. Etude et Travaux, 3, 
42-49.

[4] Mohamed, E. (2014) The Conservation Methods of Archaeological Buildings Situated within Urban Surroundings in Cairo, with Application on Case Studies of the Archaeological Islamic Buildings, Located Saladin's Square. A Thesis for the Degree of Doctor of Philosophy, Archaeology Conservation Department, Faculty of Archaeology, S.V.U University, Tirupati.

[5] Hemeda, S. (2019) 3D Finite Element Coupled Analysis Model for Geotechnical and Complex Structural Problems of Historic Masonry Structures: Conservation of Abu Serga Church, Cairo, Egypt. Heritage Science, 7, Article No. 6. https://doi.org/10.1186/s40494-019-0248-z

[6] Hemeda, S. and Atalaa, T.A.E.M. (2019) Intervention Retrofitting and Rehabilitation of Al-Gawhara Palace at the Saladin Citadel, Cairo, Egypt. Open Journal of Geology, 9, 109-141. https://doi.org/10.4236/ojg.2019.93009 http://www.scirp.org/journal/paperinformation.aspx?paperid=90923

[7] Ukasha, T. (1990) Egyptian Art. The Egyptian General Book Organization, 344.

[8] Tawfik, S. (1990) History of Architecture in Ancient Egypt (Luxor), Dar al-Nahda al-Arabiya.

[9] Arnold, D. (1991) Building in Egypt: Pharaonic Stone Masonry. Oxford University Press on Demand, Oxford. https://books.google.com.eg/books?hl

[10] Shaw, I. and Nicholson, P.T. (2008) The British Museum Dictionary of Ancient Egypt. British Museum Press, London.

[11] Arnold, D. (2003) The Encyclopaedia of Ancient Egyptian Architecture. Siglo XXI.

[12] Carruthers, W. (2009) Walter Bryan Emery and the History of Egyptology. Antiquity, p. 83.

[13] Shaw, I. and Nicholson, P.T. (2000) Ancient Egyptian Materials and Technology. Cambridge University Press, Cambridge.

[14] Stocks, D.A. (2013) Experiments in Egyptian Archaeology: Stone Working Technology in Ancient Egypt. Routledge, Abingdon-on-Thames. https://books.google.com.eg/books?id

[15] Golvin, J.C. (1995) Enceintes et portes monumentales des temples de Thèbes à l'époque ptolémaïque et romaine. $\mathrm{Na}$.

[16] Leblanc, C. and Mohamed, M. (1990) Fekri, Les enfants de Ramsès 2 au Ramesseum. Memnonia, 1, 91-108.

[17] Mohamed, E.H. (2019) The Effect of the Reciprocal Relations of the Deterioration Symptoms in Different Building Materials in Some of Historic Cairo's Buildings. Resourceedings, 2, 167-184. https://doi.org/10.21625/resourceedings.v2i2.612

[18] El-Derby, A. (2010) Some Construction and Building Defects in Ancient Egypt Buildings Which Have Played a Role in Own Deterioration and Damage. The First International Conference on Science in Ancient Egyptian Civilization, April 2010, 320-358.

[19] Mohamed, E.H. (2019) Using of GIS Technology for Conservation of the Ottoman Bathroom and Its Urban Surrounding in Qena Egypt. Archaeological Discovery, 8, 26-46. https://doi.org/10.4236/ad.2020.81002

[20] Karakhanyan, A., Avagyan, A. and Sourouzian, H. (2010) Archaeoseismological Studies at the Temple of Amenhotep III, Luxor, Egypt. Ancient Earthquakes, 471, 199. https://www.researchgate.net/publication/236960355 https://doi.org/10.1130/2010.2471(17) 
[21] Maamoun, M., Megahed, A. and Allam, A. (1984) Seismicity of Egypt. Bulletin of the Helwan Institute of Astronomy \& Geophysics, 4, 109-160.

[22] Dolinska, M. (2007) Temples at Deir el-Bahari in the New Kingdom 6. In: Haring, B. and Klug, A., Eds., Aegyptologische Tempeltagung, Funktion und Gebrauch Altaegyptischer Tempelraeume, Wiesbaden, Leiden, 4-7.

[23] Kebeasy, R.M. (1990) Seismicity. In: Said, R., Ed., the Geology of Egypt, A. A. Balkema, Rotterdam, 51-59. https://doi.org/10.1201/9780203736678-5

[24] Sieberg, A. (1932) Untersuchugeb uber erdbeben und bruchschollenbau im oslichen mittelmeergebeit; Denkschriften der medizinisch naturwissenschaftlichen. Gesselschaft zu Jean, 18, 161-273.

[25] Badawy, A., Abdel-Monem, S.M., Sakr, K. and Ali, Sh.M. (2006) Seismicity and Kinematic Evolution of Middle Egypt. Journal of Geodynamics, 42, 28-37. https://doi.org/10.1016/j.jog.2006.04.003

[26] Haggag, H.M., Gaber, H.H., Sayed, A.D. and Ezzat, M. (2008) A Review of the Recent Seismic Activity in the Southern Part of Egypt (Upper Egypt). Acta Geodynamica et Geomaterialia, 5, 19-29.

[27] Korjenkov, A.M. and Kaiser, D. (2003) Historical-Macroseismic Study of the Town Church in Wittstock, Northern Germany. Proceedings, 11 th FIG Symposium on Deformation Measurements, Santorini, 423-430.

[28] Dogangun, A. and Sezen, H. (2012) Seismic Vulnerability and Preservation of Historical Masonry Monumental Structures. Earthquake and Structures, 3, 83-95. https://doi.org/10.12989/eas.2012.3.1.083

[29] El-Derby, A.A.O.D. and Elyamani, A. (2016) The Adobe Barrel Vaulted Structures in Ancient Egypt: A Study of Two Case Studies for Conservation Purposes. Mediterranean Archaeology and Archaeometry, 16, 295-315. 